\title{
Queering/Querying Cosmopolitanism: Queer Spaces in Shanghai
}

\author{
By Hongwei Bao
}

\begin{abstract}
This article examines different types of queer spaces in contemporary Shanghai together with the various same-sex subjects that inhabit these spaces. In doing so, it discusses the impact of transnational capitalism, the nation state and local histories on the construction of urban spaces and identities. Combining queer studies and urban ethnography, this article points to the increasing social inequalities hidden behind the notion of urban cosmopolitanism created by the deterritorializing and meanwhile territorializing forces of transnational capital and the state. It also sheds light on how these various identities and spaces are lived and experienced by ordinary people, as well as possible ways of resistance to the dominant narratives.
\end{abstract}

Keywords: Cosmopolitanism, Shanghai, queer space, gay, tongzhi 


\section{Introduction}

Shanghai appears to be run by youth, staffed by youth, and patronised by youth. The population now exceeds 20 million ... Nearly every gay you meet in China says they want to live here. The nightlife is constantly reinventing itself, but many venues have found consistent patronage from young, professional locals and expats. Shanghai has come to rival Hong Kong as the gay centre of China as the winds of freedom continue to blow. (Utopia Asia 2009)

In the not terribly distant future, we'll be talking about the Shanghai club scene the way we discuss Sydney, London, San Francisco, or any other major international destination. It's a matter of when, not if. (Collins 2009)

Shanghai has recently become known as the gay capital of China. The Independent lists Shanghai as one of the world's five most improved cities for gay tolerance (2008). ${ }^{1}$ Utopia-Asia.com, a lesbian, gay, bi-and transsexual (LGBT) web portal in Asia, claims that every gay man in China wants to live in Shanghai. Fudan University in Shanghai is the first university in mainland China to offer courses in gay studies (Gao 2006). ${ }^{2}$ China Daily celebrated Shanghai as 'one of the most open and progressive Chinese cities' following the success of the 2009 LGBT Pride Week. This celebration also strengthened this image of Shanghai as a gay metropolis. In a week-long period from June 7 to 14, 2009, Shanghai celebrated what its organisers called 'China's first LGBT festival', with parties, performances, film screenings, art exhibitions, panel discussions, BBQs, and 'gay weddings'. ${ }^{3}$ Although the event organisers, mostly foreign expatriates working in Shanghai, claim that this is China's first-ever LGBT festival, others, mainly Chinese lesbians and gays, argue that this claim is no more than a strategy for publicity. Since the 1990s, LGBT activists in Beijing and other parts of China have launched various campaigns which may be called 'LGBT festivals'. However, one interviewee who works for a local LGBT NGO said that the event organisers of the Shanghai Pride know better how to do PR (public relations) than their Chinese counterparts. The disagreements and clashes between local Chinese LGBT individuals and organisations and international expats based in Shanghai are well worth our attention, as they remind us of the heterogeneity of LGBT communities and identities in China. They have an impact on the construction of different queer spaces and identities in Shanghai.

More than one thousand beautifully-dressed gays and lesbians, both locals and foreign expatriates, together with tourists, packed the festival venues on Pride Day. The event attracted wide media coverage, including the BBC, New York Times, Newsweek and China Daily. Although government intervention forced the organisers to cancel a few events, including one film screening, one theatre performance, and one social mixer, the Pride Week was still considered a great success. Despite the cautiousness of Chinese-language newspapers in reporting the event, China Daily, China's national English newspaper, commented that:

Shanghai Pride 2009 should be a source of great encouragement to the tens of millions of 'comrades', as homosexual men and women are called in the Chinese mainland. Meanwhile, the festival, though bereft of the massive street parade that is a 
feature of gay and lesbian festivals elsewhere, is also sending a strong signal to the

1.3 billion Chinese about greater acceptance and tolerance. (China Daily 2009)

The purpose of my fieldwork in Shanghai from 2008 to 2009 was twofold: first, to find out whether people, especially those within Shanghai's LGBT communities, think of Shanghai as a 'gay city'; second, to examine what types of 'queer spaces' are available for LGBT people in Shanghai and how they are related to particular constructions of gay identity. Drawing on Henri Lefebvre (1991) and Michel Foucault (1978, 1986), I also aim to delineate the complex relation between identity construction and spatial formation evident in the queer spaces of Shanghai. Besides, I will discuss how queer culture in Shanghai is configured within the abovementioned debates..

\title{
Queer Spaces and Imagined Cosmopolitanism
}

Queer space, in Ira Tattleman's words, involves

\begin{abstract}
the construction of a parallel world, one filled with possibility and pleasure, while functioning simultaneously as an intervention in the world of dominant culture. [...] Queer space provides an alternative means of worldly inhabitation, makes visible the already in-place hierarchies, and embraces the reciprocity of space and sexual identity. In its place of opportunity, we are free to construct ourselves in flexible, unspecified, and unpredictable ways. (Tattleman 2000: 223-224)
\end{abstract}

Tattleman seems to be very optimistic about the new possibilities that queer space brings about. I, however, wish to emphasise the point that queer space 'makes visible the already in-place hierarchies' (Tattleman 2000: 224).

Like Binne and Skeggs, I wish to point out the issue of class in the production of queer spaces: 'behind and within the articulation and desire for the fluidity of identity associated with the use of the term cosmopolitan, the rigidity of class and lesbian and gay identity are produced' (Binne \& Skeggs 2006: 221). They further emphasise the issue of class in such articulations: 'class entitlement plays a major role in articulating and enabling who can be included and excluded from this space.' (p. 221)

The two epigraphs to this article, despite their differences, demonstrate the central role that sexuality plays in constructing an 'imagination' of cosmopolitanism, both for Shanghai and for China, both by foreign visitors and by the Chinese who live in the city. Cosmopolitanism has been a contested concept in academic discussions in recent years (Brennan 1997; Yang 1997; Robbins et al. 1998; Schein 1999; Beck 2000, 2002, 2004, 2006, 2007; Appiah 2006; Binnie 2006; Morgan \& Banham 2007; Rofel 2007; Donald et al. 2009; Harvey 2009). It is understood both as a philosophy of world citizenship which transcends state boundaries and a term for people's skills and attitudes towards diversity and difference (Binnie \& Skeggs 2006: 13). In this article, I deploy the concept of 'imagined cosmopolitanism' developed by anthropologist Louisa Schein (1999), who in turn draws on Benedict Anderson (1983) to highlight the ways in which cosmopolitanism works 
as a social imaginary shared by people who may never have met each other but who embrace a common sense of belonging and aspiration:

Imagined Cosmopolitanism, then, is about conceiving a tauntingly chimeric world of spatial, class, gender, and race mobility, where State borders and economic exclusions cease to be intransigent constraints. ... At the same time, it is fundamentally about the endurance of immobility. (Schein 1999: 223-224)

That this sense of commonality is imagined does not necessarily render the feeling of being cosmopolitan less real. Admittedly, imaginations have performative dimensions and are often translated into social realities through people's lived experiences.

Schein observes that people in post-socialist China produce individualities (which they often believe should break away from socialist collectivism) in innovative ways including by participating in practices of consumption. Such participation is not, however, equally available to every member of the society in the same way. Schein stresses that it is important to 'put some inequalities back into the picture':

Assuming a state of generalised yearning, then, does not presume that all who crave goods are equally driven to produce distinct selves through acquisition. Just as the structures of feeling around transnational commodity desire differ in each historical moment, so too is the political-economic context for those desires highly divergent. (Schein 1999: 369)

Certainly people from different social backgrounds may imagine cosmopolitanism in divergent ways according to their socio-economic constraints. It is also necessary to be aware of the potential risk of structural determinism in Schein's argument. Indeed, we should caution against both a deterministic and a voluntaristic reading of 'imagined cosmopolitanism'. It is useful to bear in mind that such imaginations - in line, also, with the Bourdeuian notion of 'habitus' (Bourdieu 1984) —are the effect of interplay between individual and social structures.

Schein's focus on consumption risks obscuring the importance of the nation state in shaping such dispositions. Mayfair Mei-Hui Yang (1997) brings our attention to the divergence of interests between the nation and the state and to the role of mass media in 'deterritorialising' people's desires. For example, Lisa Rofel (1999, 2007) highlights the central role that gender and sexuality play in imagining 'other modernities' and a 'desiring China'.

Ulrich Beck (2007) defines cosmopolitanism as the 'erosion of distinct boundaries and the emergence of internal globalisation or dissolution of the nation state in which the "us" and "them" of social identities is constructed less negatively'. His vision seems extremely utopian. Certainly, the power of the nation state in constructing sex and sexuality has not diminished. Apart from a heightened sense of national identity ('Chineseness'), gays and lesbians in Shanghai also subscribe to a distinct local identity ('Shanghaineseness'). People I interviewed seem to agree that there is not only a cultural specificity attached to the Chinese tongzhi 
identity, which differs greatly from Western 'gay', but a cultural specificity that is attached to regional cultural differences.

People often attribute two characteristics to LGBT culture in Shanghai. First, gays and lesbians in Shanghai know how to take care of themselves and how to enjoy life. As Eddy, the boss of Eddy's Bar, explained, gay people in Shanghai 'know how to take care of their bodies and the importance of going to sleep early'. If consumption constructs one aspect of local gay identity, pragmatism is another characteristic of Shanghai gay culture frequently contrasted with the 'irrationality' of LGBT people in other cities:

\begin{abstract}
In Beijing, they're much more open and passionate about it. They go with the flow and then pay the consequences. Here, in typical Shanghai style, everyone is always calculating. They're always thinking of the consequences of their actions. If you go to a disco in Dalian [in northeastern China's Liaoning province], when the hip music goes on, everyone heads for the dance floor. In Beijing, half the people do and in Shanghai, no one does, then suddenly someone saunters up there. (Yatsko 2003: 206)
\end{abstract}

This 'rationality' can be understood using the capitalist logic of production and consumption, as Max Weber (1976) points out. The widely acknowledged image of Shanghainese pragmatism and sophistication is closly tied to Shanghai's role as the capital of finance and commercialisation in China (Lee 1999; Wasserstrom 2009). Therefore, it is understandable that Beijing and Shanghai, are imagined in different ways: 'Beijing as a space for performing identity, and Shanghai as a space to be consumed' (Visser 2010: 21). One gay Chinese-American who lived in both Shanghai and Beijing, claimed that Shanghainese rationality is more 'modern' than the unsophisticated folks in other parts of China. Popular jokes have it that Shanghainese consider people from other parts of the country 'country bumpkins' (xiangbalao). Shanghai's gay identity bears the imprint of this selfidentified cultural superiority brought about by their experience with colonialism and capitalism in the twentieth century.

While I do not think that the generalisations with which my respondents work are necessarily accurate, I am interested in why people subscribe to such distinctions. I can sense the impact here of a rising cultural nationalism in modern and contemporary China that has constructed a new version of the China/West binary, along with the ambivalent antagonism embedded in such a dichotomy. It also reflects a strong sense of locality tied to regional differences within China, a legacy which derives from the past. The household registration system (hukou) has, to a great extent, constructed a heightened sense of local identity. Hukou gives each person an identity that is tied up to geographical location. Where one comes from becomes an enduring marker of one's identity in China. ${ }^{5}$ The uneven regional and local development has reinforced this sense of differences.

It also sheds interesting light on why people subscribe to such regional and local differences within gay culture, and what state policies may mean to ordinary people’s lived experiences, feelings and emotions, including in gay culture. In- 
deed, identities not only provide people with a sense of belonging, they may also serve as a type of politics which constitutes people's daily experiences. As state policy makes local identities possible, local people also utilise these identities to resist and to subvert the state discourses.

Cosmopolitanism as a social utopia also coincides with growing social inequalities manifested in urban spaces. In their study of the production and consumption of cosmopolitan space in Manchester's Gay Village, Jon Binnie and Beverley Skeggs (2006) call for a reconsideration of social inequalities within cosmopolitanism and highlight the intersection of sex and class. Like Manchester, queer cosmopolitanism in Shanghai is fraught with hopes and despairs, tensions and precariousness, with its evident racial and class politics as well as its reference to an urban/rural divide. As Bruce Robbins (1998) cautions, cosmopolitanism should not be considered as a utopian world of universal love and mutual understanding, instead it points to a domain of contested politics. Similarly, as Rofel (2007), Schein (1999) and Yang (1997) point out, the imagination of cosmopolitanism in China remains closely tied up to both global capitalism and neoliberalism. The ability to negotiate cosmopolitanism is certainly classed, raced, gendered and sexed. These disparities are manifest in the different queer spaces in Shanghai that I will discuss below.

\section{Sex and the City: Queering Shanghai's Cityscape}

Shanghai has always been imagined as a gendered and sexualised city in popular cultural representations: for many Shanghai's twentieth-century modernity was embodied in women and prostitutes (Hershatter 1997; Lee 1999; Wang 2007). The city was simultaneously called the 'Paris of the Orient' and 'whore of the Orient' in the colonial era (Yatsko 2003). The experiences and passions of foreign expatriates, tourists, compradors, literati, women, and prostitutes made the city extremely 'sexually attractive' in the 1920s and 30s (Lee 1999). After 1949, the communist regime transformed Shanghai into an industrial city and a city with 'grand revolutionary traditions'. Prostitutes and homosexuals, who used to hallmark the city's cosmopolitanism, were forced to transform themselves into socialist subjects at the beginning of the Maoist era. This was reversed by the 'Reform and Opening-Up' since the 70s (Farrer 2002). A booming sex industry and a vibrant youth culture have returned to the city. It stands at the forefront of 'imagined cosmopolitan’ and, as Rofel (2007) puts it, a ‘desiring China'.

Gay spaces in Shanghai have undergone significant changes in the past three decades. According to Lee San, a local gay man whom I interviewed during my fieldwork and who lived through the changes of Shanghai's gay scene in the past decades, Shanghai's gay public space started in the 1970s and 80s with scattered 'beats' (dian'er), or cruising places such as parks, river banks and public toilets. One of the earliest meeting places for gay people, according to him, was the small 
roadside park at Hankou Road. Together with its adjacent areas, including the Bund and the banks of the Suzhou River, this part of town was called 'the Golden Triangle' (jin sanjiao) by local gay people. In a popular online lesbian story titled Past Things in Shanghai (shanghai wangshi), Zhang Haoyin (2003) recalls:

The Bund is a strange place. She [referring to the Bund] is always changing. In the 1980s, there was the 'lovers' wall' (qinglü qiang). [The place was so busy that] sometimes people had to pay in order to secure a place here. There were also jobless young people who hang out there. Later, together with the newsstand at Fuzhou Road, the Bund formed a 'homosexual triangle' (tongxinglian zhijiao). You could often see single handsome young men standing there and looking around, or several young people flirting and laughing together. There was inexhaustible energy in them. 6

In recent years, shopping centres, restaurants, cafes and bars have been popular meeting places for relatively well-off young gay people in Shanghai. The density of population in these public spaces makes it relatively safe for LGBT people to meet. Apparently, the risk of encountering thieves, robbers and 'money boys' (male prostitutes) has been a continuing concern for gay people who visit public queer spaces. These commercial queer spaces are also often places for publicly representing, and thus often symbolise, fashion, lifestyle and class distinction. In my interviews with LGBT people in Shanghai, many people choose meet me at Starbucks. One interviewee explained to me that cafes and bars have a 'petit bourgeois ambience' (xiaozi qingdiao). The common phrases 'petit bourgeois ambience' and 'middle-class lifestyle' bespeaks young people's understanding of cosmopolitanism as deeply intertwined with class, and the desire of belonging to certain classes.

My local gay guide Lee San explained that the self-identified gay bars and clubs began to appear in Shanghai in the early 1990s. Eddy's and Erdingmu were among the first pink bars in Shanghai. They shifted their locations many times and were closed several times for various reasons. ${ }^{7}$ More bars mushroomed in the late 1990s, together with numerous clubs (huisuo), saunas, hair salons, and massage parlours. Many of these commercial venues are located west of the Huangpu River and inside the main city centre or districts such as Jing'an, Luwan, Huangpu, and Xuhui. Their geographical locations become a dominant factor in attracting different groups of clientele. Generally speaking, commercial venues in the inner city areas are more attractive to international and middle-class customers, whereas venues in less favourably-located districts, such as Yangpu and Hongkou, cater mostly to working-class and migrant customers. This brief introduction to Shanghai's erotic landscape calls for details and nuances. Although such an approach to Shanghai's local gay history may help people who are not familiar with the topic to grasp a broad picture of its background, the shortcomings of such a description will be demonstrated in the next few sections.

Gay bars and clubs in Shanghai should be understood both as transnational queer spaces and social spaces linked to homoeroticism in China's historical past. 
Before 1949, urban queer spaces existed mainly in classical Chinese opera theatre (Sang 2003; Jiang 2009; Liang 2010). The theatrical space was where desire and money were exchanged, often between rich patrons and poor singers. Homoeroticism, considered an 'obsession' (pi), was widely practiced in that setting ( $\mathrm{Wu}$ 2004; Kang 2009). The reform of opera theatres in 1949 changed the function and status of the theatre. The theatre becomes a formal location with little public personal desire exchanged between the performers and the audience. Instead, this social function is later transferred to pubs and clubs, where the exchange of money and desire usually takes place between performers and clients. These gay bars and clubs are not simply commercial and recreational spaces influenced by transnational practices; they are also new social spaces developed in connection with China's historical social spaces. ${ }^{8}$

At around the same time as this expansion of gay social spaces, the use of the Internet became more and more popular in the gay community. The internet has been the preferred way of dating for many gays and lesbians because of its anonymity and the ease of locating people through queer websites, compared to the difficulty and the risk involved in off-line dating. Time magazine noted in 2001 that what the Internet had done to Asia's gays and lesbians in five years equalled what the Stonewall had done in the West over a period of twenty-five years (Martin, et al. 2003: 2). This is certainly true to China. China's LGBT community 'pink paper' notes the important role that the internet plays in the construction of LGBT community in China. According to its statistics, there were more than 160 LGBT websites in China in July 2000. The number increased to 340 in June 2004. In 2006, there were more than 3,000 LGBT websites in the form of personal web pages or blogs. Boysky (yangguang didai), a gay community web portal, has a click rate of 70,000 times a day (Tong 2008: 177-178). The increasing popularity of LGBT websites in China contributes to new forms of sociality and community. Many people meet online first, followed by an offline meeting. They not only meet online through gay websites and QQ (a Chinese-language instant messenger) groups, but meet offline to have parties, play sports and engage in other community activities. ${ }^{9}$ The online space and the offline space are increasingly intertwined.

Alongside this change, new forms of public gay organisation also appeared. With the increase of the public awareness of HIV/AIDS issues in China, more and more LGBT NGOs were set up by various international foundations and by the Chinese government. ${ }^{10}$. The Chinese government began to acknowledge the existence of LGBT groups and the importance of HIV/AIDS prevention in the late 1990s. Although the link between LGBT identities and public health discourse may contribute to the further stigmatisation of LGBT identities, an increasing number of LGBT NGOs were established with the help of transnational capital and the Chinese government (Center for Disease Control and Prevention) (He 2006; Jones 2007; Li 2004). Some of these NGOs are devoted to HIV/AIDS prevention; others are more interested in community building. China's LGBT NGOs 
started from community hotline and newsletter in the late 1990s. The earliest LGBT NGOS include: the Beijing Tongzhi Hotline started in 1997 and the Friend Exchange (pengyou tongxin) community newsletter in 1998. After 2000, with Chinese government's recognition of the HIV/AIDS issue in China, more and more NGOs were founded. There were more than 120 LGBT NGOs in China in 2007 (Tong 2008: 248). The number has been increasing each year. Most of the NGOs were funded by international foundations such as the Ford Foundation, the Bill and Melinda Gates Foundation and the Chi-Heng Foundation. Some were established by National Centre for Disease Control (CDC) affiliated with China's Ministry of Public Health, and they were often referred to as Government NGOs, or GoNGOs. Many NGOs and GoNGOs often compete against each other due to limited funding and limited community resources. At the National Conference on HIV/AIDS Prevention and Treatment among Men Who Have Sex with Men that I attended in November, 2008, the clash of interests among different NGOs became the spotlight of the conference. ${ }^{11}$ Such phenomenon has often been described as neihong (internal struggle) or butuanjie (not being united) (Ho 2005).

There is no shortage of such LGBT NGOs in Shanghai. A gay man who works for an LGBT NGO told me that LGBT NGOs in Shanghai are 'better' than those in other cities, meaning that the NGOs in Shanghai are less antagonistic to each other. Shanghai's prominent position in transnational capitalism has contributed to its increasing significance in global biopolitics. Almost no philanthropic organisations will miss out Shanghai in their implementation of humanitarian programs in China. Each organisation in Shanghai has its clear range of responsibility and target groups, and hence their interests do not clash directly. He attributes this to the less political, less aggressive and more pragmatic personality of the Shanghainese, which I will address later. The financial support from international foundations competes intensely against the Chinese government's reassertion of its power over the LGBT community in China. The establishment of, and competition among, NGOs and GoNGOs would not have been possible without the cooperation and competition between transnational capitalism and the Chinese state.

In this process, a new social identity, 'Men Who Have Sex with Men' (nannan xing xingwei renqun), or MSM, has been constructed by the public health discourse. The English abbreviation of the term, MSM, has been widely used by the Chinese government and LGBT NGOs in HIV/AIDS prevention. Interestingly, not everyone in China speaks English and can articulate the term clearly. These slippages in mimicry bespeak the complex process of cultural translation and demonstrate the ambivalent agency of the non-Western cultures in globalisation (Bhabha 1994). 


\section{Transnational and Commercial Queer Spaces}

Successful as the Shanghai LGBT Pride Week in June, 2009 was, careful observers are quick to point out that its organisers and participants are predominantly Western, white and middle class. The working language of the festival was a mixture of English and Chinese. The logos, banners, advertisements, and even the website of Pride Week were exclusively in English. The event organiser offered many reasons for this to the press. One of them is as a precaution against the Chinese government's possible intervention. Drawing on the lessons of failed LGBT cultural festivals and queer film festivals held in Beijing in the past few years, the organisers of the Shanghai Pride decided to limit publicity to an English-speaking audience. ${ }^{12}$ Despite this precaution, the organisers were still warned by the police to limit the crowds, to keep the noise down, and were required to cancel some events. ${ }^{13}$ However, negotiating with the Chinese state was not the only reason for organisers to use English for event publicity. The organiser, Shanghai LGBT Group, was established by foreign expatriates and the group's working language is English. They have an online yahoo group web page which publishes event information in English every week. These events include pub quizzes, scavenger hunts, bowling, dinners, wine tasting, and pub nights. Most of these events are not cheap for a local consumer. The high entrance fee for the festival also excluded many people: the inaugural dinner cost $150 \mathrm{RMB}$ and the wine tasting party another 150 RMB. 'We welcome local participants,' an organiser explained to me. 'And we also want to make sure that the participants are within a manageable number and that they feel comfortable with each other'.

'Feeling comfortable' is less about the number of participants than about class. The correlation between cosmopolitanism and class becomes pertinent here. For some foreign expatriates, working in a big metropolis like Shanghai, witnessing the rapid changes of the city, experiencing the excitement that the vibrant city life offers, in addition to having some local Chinese friends, constitutes their cosmopolitan disposition. For their Chinese counterparts, being able to participate in the 'global gay' (Altman 1997) scene with their international friends is equally symbolic of their cosmopolitanism. In both cases, cosmopolitanism is a habitus, a certain disposition intrinsically related to certain social classes into which one is born and to which one belongs (Bourdieu 1984). Indeed to be gay is like having the 'sexual capital' which places one in certain social strata with certain material and imagined privileges. For example, many gay people in Shanghai feel that they are better positioned in Chinese society because they have more direct access to the international expatriate community in the city. One does not necessarily have to work in a foreign enterprise in order to meet people from other countries and cultures. The feeling of sharing the same sexual identity provides a sufficient reason for a local gay man to sit together with and to start a conversation with a Caucasian who comes from another part of the world. This makes some gay people in 
Shanghai feel that they are more urban and cosmopolitan than gay people in other cities that have less knowledge about the West.

Apart from an imagined gay cosmopolitanism, being gay also establishes a set of hierarchies experienced as internal to gay culture. For Chinese gay men in Shanghai, the ability to communicate in English, having a group of international friends, reading local English newspapers such as That's Shanghai or City Weekends, going to the regular 'meet and greet' night on the last Thursday of each month at Frangipani, and enjoying a cocktail are the kind of activities that locate one within the Shanghai-based version of a 'global gay' scene. Needless to say, being this type of gay person does not come cheap, and not everyone is able to be gay in this way. Some local Shanghai gay men I interviewed remarked that they did not know about the LGBT Pride Week until it was over. Others expressed a lack of interest, stating that it was the 'foreigners' business' and not designed for the Chinese. The type of 'global gay' identity represented by the glamorous Shanghai LGBT Pride is as exclusive as it is inclusive.

On 12 December 2008, I attended a gay theatre première also organised by the Shanghai LGBT Group. Australian theatre producer and director Michael Darragh put on the British gay play The Beautiful Thing together with a group of foreign expatriates based in Shanghai. The play was performed in English, with a predominantly Caucasian cast and audience. To 'localise' the play, the director chose Derek Kwan, an Asian American who works in Shanghai, to perform the role of Ste. A small number of local participants in the audience were either fluent English speakers or came along with their Caucasian friends. Many of these also worked in foreign enterprises or joint ventures and many had studied or worked abroad. My interviews with them demonstrated that most of them were confident about the future of Shanghai. They cherished the work opportunities available in Shanghai and which, according to them, may not be available to those Chinese living abroad. They seem to have what Aihwa Ong refers to as 'flexible citizenship', grounded in

the cultural logics of capitalist accumulation, travel, and displacement that induce subjects to respond fluidly and opportunistically to changing political-economic conditions. In their quest to accumulate capital and social prestige in the global arena, subjects emphasize, and are regulated by, practices favouring flexibility, mobility, and repositioning in relation to markets, governments and cultural regimes. (1999: 6)

Ong correctly points out that the mechanism on which such 'flexible citizenship' relies is the transnational flow of capital, which has made the transnational flow of population possible. In an article on media and cosmopolitanism in Shanghai, Yang also discusses the 'deterritorialising' effect of transnational capitalism on the Chinese state (1997: 297-298), arguing that the stability and rigidity of state logic is challenged and undermined by the restless and fluid nature of capitalism. Quoting Deleuze and Guattari, Yang highlights the 'flows of desire that capitalism unleashes' (Yang 1997). Here the term 'desire' refers to a broad range of 'dreams, 
longings and aspirations that the Chinese citizen embodied' (Rofel 2007: 25). However, I believe that the use of the term by Deleuze and Guattari has not sufficiently addressed sex and sexualities.

John D'Emillio (1997) has demonstrated that gay identity is a product of capitalism. This was echoed by Dennis Altman (2001), in his controversial book Global Sex, which observes the dissemination of gay identity from EuroAmerican West to other parts of the world. Although people tend to accuse Altman of being Eurocentric (or, rather, American-centric) (Martin 2008; Martin et al. 2003; Rofel 2007; Sullivan \& Jackson 2001), there is some truth in his argument about the eroding forces of global capitalism and the new sexual subjectivities emerging in and beyond the nation state. Altman cautions against seeing these new sexual subjectivities as a replica of Western gay identity:

\footnotetext{
Homosexuality becomes a particularly obvious measure of globalisation ... Yet we must beware reading too much into these scripts. What is happening in Bangkok, Rio and Nairobi is the creation of new forms of understanding and regulating the sexual self, but it is unlikely that they will merely repeat those forms which were developed in the Atlantic world. (Altman 2001: 100)
}

If we only focus on the glamour of gay scenes in bars and clubs, we may well get the impression that the gay scene in Shanghai testifies to Altman's prophecy of 'global queering' (Altman 1996). At ten o'clock on a Saturday night, I find myself at 1877 Huaihai Zhonglu in the former French concession, Eddy's, one of the longest continually open gay bars in Shanghai. The bar has a world-class design, with red lighting, Chinese antiques, and modern art. The red lighting at the bar is designed to create an effect of ambiguity, connoting both sexual innuendo and political subversion. Most eye-catching are the paintings on the wall portraying the Maoist 'comrade', serving as both a pun and a parody of communist ideology. The crowd is a mixture of foreign expatriates and local Chinese. English seems to be the working language. The bartender is busy but friendly. One glass of beer, Budweiser or Corona, costs 30 to 40 RMB. The DJ is playing trendy music mixed with a global flavour, but not loud enough to disturb conversations. Men in tight T-shirts and jeans show off their well-toned bodies. The Chinese gay men here are mostly in their 20s or 30s and they are young, relatively well-off and very confident. They proudly command both economic and cultural capital and are active participants in the transnational gay scene. This might be anywhere in the world: London, Paris, Berlin, New York, or San Francisco. It seems in this place that Shanghai has become a very transnational and cosmopolitan city for gays and lesbians. The Chinese gay men at Eddy's also seem to have Ong's 'flexible citizenship'. Some work in international companies and travel to different parts of the world. They appear to negotiate their sexual identity and cultural identity with ease: their being gay is not apparently in contradiction with their being Chinese. It is a 'double consciousness' of being both Chinese and transnational that gives the gay scene in Shanghai a sense of exoticness to both Chinese and foreign residents and visitors. 
Most of the people whom I met in events organised by Shanghai LGBT groups and at these commercial gay bars identified themselves as 'gay', as in the frequently-used phrase 'wo shi gay' ('I am gay'). The English word is not often translated into Chinese even in a conversation in Chinese. It does not need to be. It both embraces a transnational and cosmopolitan identity and manifests a classical Chinese aesthetics of hanxu (implicitness or reticence), that is, one does not need to articulate it clearly, at least not in Chinese. ${ }^{14}$ Code switching, in this context, is an indirect gesture of 'coming out': it suggests a move to 'moving out', but the 'coming out' is apparently limited to people who understand English, who have similar educational and class background. The English term 'gay' in this context can be considered both an 'out' strategy and a closet. Fran Martin discusses the dual, and ambivalent, meanings of 'coming out' politics in Taiwanese society in her book:

\begin{abstract}
I want to suggest that the pervasive practice of a particular way of representing homosexuality in contemporary Taiwan, one that inscribes 'tongxinglian' as animated by an incessant movement between the poles of the hidden and the shown. Specifically, the discourse I am referring to tends to appeal to a dynamic alteration between the state of yin (concealment) and xian (disclosure), for example in such phrases as yin er wei xian (concealed and undisclosed) or ru yin ruo xian (now-concealed, now disclosed) which cluster particularly thickly around figurations of homosexuality. (Martin 2003: 189)
\end{abstract}

Such insight certainly holds true in mainland China. This discussion of the yin/xian dynamics is comparable to the Western gay identity politics discussed by Eve Sedgwick (1990). As Sedgwick argues in Epistemology of the Closet, homosexuality is closely related to several binary oppositions in Western popular culture, including secrecy and disclosure, as well as the public and the private. One has to be either 'closeted' or 'out'. 'Coming out' is encouraged in the gay identity politics in the West, as it is directly related to the notions of 'truth' and 'authenticity', two privileged terms in the modern episteme. The importance of seeing and visibility is also raised. This is similar to Martin's account which points to the complexities and nuances of the 'closet' and 'coming out' politics in the Chinese context, in which dichotomies such as out/in, visibility/ invisibility, and authenticity/ inauthenticity become blurred and contested. The only exception in the Chinese context is that concealment and disclosure do not point to the authenticity of one's identity. Rather, they are historically and socially contingent. Indeed, for many gays and lesbians in China, one does not need to be completely 'in' or 'out'. Being 'in' and 'out' depends on the particular social setting and on the person that they are with. When to conceal and when to disclose one's identity, together with to whom, becomes a matter of politics.

It is worth mentioning that such 'global gay' identities are also products of capitalist consumption, which break away from old forms of social relations, be they Confucian ties of family and kinship, or socialist collective identities. It seems that this 'global gay' identity is among the new identities that capitalism - 
with that dissolution of fixed, fast-frozen relations evoked in Marx and Engles' Communist Manifesto (1977) - has brought about. But it would be problematic to attribute it entirely to capitalism in this way. The state also plays an important role in constructing identities and producing these desires. I will discuss these issues in relation to the construction of queer culture in the case study below.

\section{Tongzhi and the Space of Morality}

At a high school gymnasium, I met Rio, Lee San, and Xiao Feilong. They are all members of a local LGBT group called Rainbow League (caihong lianmeng). Rainbow League has organised various interest groups, including sports, music, dance, reading, and foreign languages. The three people I interviewed belong to the volleyball group. They rent affordable sports venues from high schools and catch up with each other to play volleyball every Sunday afternoon. People in this group know each other quite well, regularly meeting both offline and online, given that the group has an online bulletin board and a QQ group for messages.

The Hong Kong-based Chi-Heng Foundation runs many interest groups and clubs for LGBT people, and for people who live with HIV/AIDS, in Shanghai. It plays an important role in such events as gay theatre premiere and in Shanghai LGBT Pride. It also runs a local pink magazine Shi (Yes), which tries to compete against the Beijing-based Dian (Gayspot) but without much success. ${ }^{15}$ It also operates several hotlines offering free counseling services targeting LGBT people. In the same office building at 500 Xinjiang Road, one can find Leyi, an NGO for male and transgender sex workers and Beautiful Life, an NGO for people who live with HIV/AIDS. They have a group of volunteers, mostly university students, who help distribute condoms and HIV/AIDS prevention-related booklets in the local gay and sex worker communities. People in this group prefer using the term 'comrade' (tongzhi) instead of the English term 'gay' or the often pathologised term tongxinglian (homosexual).

Tony, a volunteer who works for a local LGBT NGO, told me that he hates the term tongxinglian because it is a stigmatised name for gay people. He does not like the English term 'gay' either because it is foreign. 'Gay', for him, often conjures up the image of promiscuous Western gay guys who are sexually aggressive and emotionally unstable. Whereas, for him, tongzhi attaches more importance to qing (emotional attachment) instead of xing (sex). Tongzhi are also socially responsible citizens. They work hard, study hard, and make significant contributions to society. For this respondent, the only difference between tongzhi and straight people is their sexual orientation. Tongzhi are good citizens and thus should not be discriminated against. Those who volunteer in LGBT NGOs or participate in such community events as weekend sports are, moreover, good tongzhi. He did not mention who is not tongzhi and where the borders between tongzhi and nontongzhi might lie. But for him tongzhi is different from the both Western 'gays' or 
the Chinese gay men who hang out in Eddy's Bar. This is an argument that has also been proposed by the Hong Kong scholar and activist Chou Wah-Shan (2000). The rhetoric of suzhi ('quality') seems to dominate in the construction of tongzhi identity: tongzhi are characterised by gao suzhi ('high quality').

Suzhi (usually translated as 'quality') is a popular rhetoric in post-Mao China. It effectively distinguishes people by location, class, and education. This is a rhetoric that has been widely and effectively utilised by the Chinese government to legitimise social inequalities and to consolidate its governance. People with high suzhi enjoy more rights and privileges than people who have low suzhi. This naturalises class and gender differences as well as an urban/ rural divide. Furthermore, the state often launches different campaigns to 'improve' people's suzhi, to craft legitimate citizens, and to facilitate its governance. Andrew Kipnis (2006) even considers suzhi as a 'keyword' for understanding contemporary China's governmentality. The state-initiated discourse of suzhi, which later gained enormous popularity in people's everyday life, serves as an effective means to consolidate and reinforce social hierarchies (Donald et al. 2009; Jacobs 2009; Sigley 2009; Tomba 2009; Woronov 2009).

Tongzhi, therefore, is a sexual subject that fits into the agenda of the nation state. On the Rainbow League website, the conduct guidelines for being a good tongzhi are clearly spelt out:

\footnotetext{
Rainbow League advocates healthy lifestyles. Posting illegal, reactionary, and politically-sensitive information is strictly forbidden. Posters that do not comply with the policy will be deleted with their authors' membership deprived.
}

But if tongzhi is a legitimate political subject abiding by the rules of society and being good citizens for the state, a problem still remains between the Rainbow League's representation of the citizen and tongzhi, evidenced by the need for specific reference to the state in this warning. The citizenship of tongzhi is desexualised in public discourse. If tongzhi is indeed characterised by qing (deep sentiment) instead of xing (sex), as Chou (2000) suggests, this also means that multiplicities of sexuality have been reduced to a singularity in relation to which some forms of sexuality have been marginalised.

It is also worth noting the regional differences in queer practice unveiled by the politics of 'tongzhi'. For instance, Beijing tongzhi are perceived by my respondents as very politically-conscious and too serious. They always have numerous meetings to attend and a lot of social activism to attend to. That's why such influential LGBT events, including queer film festivals, queer art exhibitions and same-sex marriage petitions, are held in Beijing. Shanghai people perceive themselves, on the other hand, to be more relaxed and pragmatic; they celebrate everydayness and enjoy the fun that consumerism brings to them. When the Beijing tongzhi NGOs hold numerous meetings and are concerned about such grand topics as 'the future of China's LGBT movement', their Shanghai counterparts are having dinners, playing tennis, or singing Karaoke. Peter, a local LGBT NGO 
leader, told me that their organisation has to break away from its headquarters in Beijing, because the Beijing side is very dominant and bureaucratic. 'It's simply not the Shanghai style', he added.

\section{Tongxinglian and Stigmatized Queer Spaces}

Located at Anguo Road within a dilapidated working-class neighbourhood, Lailai Dance Hall is one of the older gay places in Shanghai. But maybe neither 'gay' nor tongzhi are appropriate terms to describe the people who come here. People in this venue are mostly older and more local, and they are more used to referring to themselves as tongxinglian (same-sex love; homosexuals). Lailai Dance Hall is, as the name suggests, a place for ballroom dance. Ballroom dance used to be popular in the 1920s and 30s as a sign of modernity in colonial Shanghai. They revived in the 1980s with the state call for 'reform and opening-up' (gaige kaifang) when, with the emergence of disco bars which attracted many young people in the 1990s, ballroom dance became a social marker of generation and age and a location for once fashionable youth who had become middle-aged or elderly citizens. Young men who come to Lailai Dance Hall seeking an uncle, daddy, or grandpa type of partner are ironically referred to as the 'archaeologist team' (kaogudui) in local gay slang. The dance hall only opens three nights a week: 7-9 pm every Friday to Sunday. Most middle-aged tongxinglian who come here are married men who slip away from their wives and children to meet their fellow tongxinglian at weekends. The entrance fee is not expensive, only five RMB per person. Snacks and drinks are served at supermarket prices in the dance hall. Evidently this is a place catering to people of lower social classes and with limited incomes.

The dance hall is large. People sit in groups drinking and chatting on the old sofas or plastic chairs lined up against the wall. They eat sunflower seeds quickly while drinking local-brand beer, throwing their nut skins carelessly on the floor. In the centre of the dance hall, many people dance in pairs. Most music is a slowpace waltz adapted from popular songs from the 1980s and 90s. In the front of the dance hall, there is a stage on which performers, including many cross-dressers, are singing and dancing. The whole place has a relaxing atmosphere. At nine o'clock, the music stops and people stand up and leave the dance hall. Within five minutes, the once packed dance hall abruptly empties out, with only the waiters left to do some cleaning-up jobs. Everybody seems to know where to go: the Xiahaimiao Public Garden.

Xiahaimiao is a road-side public park located within five minutes walk from the Lailai Dance Hall. Crossing the dirty neighbourhood and passing by some restaurants, hairdressers, massage parlours, and sex shops, many of which are same-sex services, the crowd arrive at a small park on the roadside. A procession of flamboyantly-dressed men cross the narrow streets, talking loudly and flirting with 
each other, as they head to their destination. People in the neighbourhood seem used to the spectacle and no one bothers to make a fuss about it.

The public garden is dark, with only a couple of roadside lamps and the lights from the shop windows on the other side of road. People sit in groups on the park benches continuing their conversation and flirtation. Many enjoy examining the passersby, assessing them for their sexual appeal. And some clearly walk up and down trying to catch others' attention. Some braver individuals directly walk up to strangers trying to make conservation, a few even beginning their greetings by touching other people's bodies. Public bodily contact seems quite common here and accepting other people's touches usually leads to more intimate touches and even to sex. A polite refusal, however, will also be understood by the other person without taking offence. In the bushes, some people have already found their sex partners and started to enjoy one-night-stand (419 in Chinese gay slang) sex. Despite the flamboyance of some, most people who come here are casually dressed. Some are also not neatly dressed at all and speak with accents from other provinces. They seem to be waidiren (people from other regions) who are often looked down upon by many Shanghainese.

One Shanghainese I talked to in the public garden expressed his contempt for 'these people' who come to the garden: 'they are waidiren', he said. According to him, some of them are migrant workers from poor areas in China. They have lower suzhi than the Shanghainese. 'Only lower-class people come here,' he said, quite oblivious to the irony of his being there himself, 'most do not have a decent income. Some even come here after nine o'clock to meet the crowd without having to pay the five yuan entrance fee at the Lailai Dance Hall.' This man also warned me that some of the young and nice-looking people are MBs (money boys, or rent boys). 'These MBs are not gay and they engage in homosexual sex only to earn money', he explained, 'these people are dangerous. Some even cheat or blackmail their clients.' His suggestion to me was not to hang out with waidiren and MBs. I was surprised that I was somehow not considered as a waidiren by him although I do not come from Shanghai. While my clothes and my standard Chinese pronunciation (putonghua) probably helped, waidiren in this context does not necessarily refer to those who are born in other Chinese cities and provinces. It is rather an identity opposed to those seeming urban and well-educated, and an abject identity cast onto people from the countryside (xiangbalao) or those who engage in commercial sexual activities.

It is widely believed in Shanghai's gay community that people who go to Ed$d y$ 's, or people who participate in the Rainbow League activities have better suzhi than those who go to the Lailai Dance Hall and the Xiahaimiao Public Garden. Such social discrimination acts like a 'structuring structure' (Bourdieu 1984) and it points to different targets in different contexts. For instance, People who go to both Lailai Dance Hall and Xiahaimoiao discriminate against people who only go to Xiahaimiao, simply because the latter have not paid five RMB to gain their 
entitlement to using a queer public space. At the Xiahaimiao Public Garden, urbanites discriminate against rural people; Shanghainese discriminate against people from other provinces; masculine people discriminate against effeminate people. Everybody seems eager to mark themselves off from such abject identities as rural people, migrant workers, and sex workers. It matters then that the rhetoric of suzhi originally came from state policy as a biopolitical strategy to facilitate the administration of populations and to and legitimise social inequalities. It has now been accepted and internalised by people who construct their own identities in reference to other identities. Across this social field the difference between 'gay', tongzhi and tongxinglian is not simply linguistic, but social and cultural as well. It unveils a multiplicity of differences and social disparities. It also points to the impact of such factors as globalisation, nationalism, and commercialisation on people’s daily lives and individual experiences.

\section{Conclusion}

I have so far discussed three types of subjects in Shanghai's gay community: the transnational and multilingual 'gay', the young and energetic tongzhi, as well as the older and often married tongxinglian. These subjectivities are not totally distinct from or exclusive of each other. They converge and overlap in different ways. A person can be gay and tongzhi and tongxinglian, depending on where he is and how he understands these terms. It is important to note that identities, and not only for gay people, are always multiple, fluid and contingent. They are never fixed or singular. We should also bear in mind that identities are as socially constructed as they are individually constructed. People do have different understandings of identities and different ways to negotiate identities. The three terms, 'gay', tongzhi and tongxinglian, are nevertheless different social identities at least because they have inherited different social, political and historical aspects of China. 'Gay' is the subject of Shanghai's transnationalism and cosmopolitanism; it celebrates the success of China's reform and opening-up to global capitalism. Tongzhi fosters a group of young, well-educated, rights-conscious and socially responsible urban youth. And tongxinglian is a term that was invented by medical and public health discourse and is the target population of HIV/AIDS prevention and police intervention. All three are positioned in a transitional era in China when gay people still have some difficulty negotiating their identities with their families, work, and the wider part of society.

These three subjects seem to have their own spaces, located in different parts of Shanghai. 'Gays' find their way to the trendy bars such as Eddy's, Shanghai Studio, D2 Club, and Frangipani, mostly located in the former French concessions and gentrified neighbourhoods (or 'gaybourhoods' in the transnational gay slang). These places are exclusive in economic and social terms. Tongzhi are happy with the more egalitarian and locally/community organised activities such as sports, 
singing Karaoke, and having dinner together. They seem more interested in 'building a harmoniously gay community' and 'improving the suzhi of the gay community', as many tongzhi websites claim. Their sense of gay space is based on morality and social responsibility. A restaurant or a sports ground can be appropriated as gay space by them under certain circumstances. And tongxinglian find their spaces in the now-unfashionable dance halls, public gardens, public toilets, saunas and bathhouses, hairdressers and massage parlours which offer sex services. Most of these places are located in poor or working-class neighbourhoods. They represent the universal side of 'queer culture' - the pragmatism and necessity of 'having sex' that is independent of social, economic and moral causes. In this way, the whole city's sexual landscape is unevenly hierarchical. Samesex practices, far from being natural or corporeal, are clearly marked by social difference.

The discourse of suzhi and people's everyday understanding of their local identities, demonstrate such impacts. However, the discourse of suzhi also encourages people to improve their lives. Local identities and regional differences can also serve as a form of cultural resistance exemplified in this case of queer culture and queer spaces. : at least it empowers Shanghai people to say no to the central government on some occasions with the statement 'This is not the way things are done in Shanghai'. Despite the state's effort in regulating queer cultural practice, the differences among various queer cultural groups are clearly demonstrated through the way queer spaces are constructed in Shanghai.

Returning to the beginning of this article then, when we say that Shanghai is a gay metropolis and that the Shanghainese embrace cosmopolitanism, we may need to ponder what type(s) of 'gay' identity we are talking about, and what is hidden beneath the gleaming dreams of Shanghai's urban cosmopolitanism that seems to bring them together.

Dr. Hongwei Bao is British Academy visiting fellow in Department of Media and Communications, Goldsmiths, University of London, UK. He has recently completed his Ph.D. thesis, titled 'Queer Comrades':Gay Identity and Politics in Postsocialist China, in Department of Gender and Cultural Studies, the University of Sydney, Australia. He has taught media studies, cultural studies, gender studies and Asian studies at the National Academy of Chinese Theatrical Arts, China; the University of Sydney, Australia, and the University of Potsdam, Germany. His research interests include queer theory, transnational and postcolonial studies, urban geography, and alternative media. Dr. Bao will start a full-time position as lecrturer in Asian media at Nottingham Trent University, UK, in February, 2012. E-mail: renebao@gmail.com 
1 This article is part of my Ph.D. research project on gay identity and community in cotemporary China funded by China Scholarship Council and the University of Sydney from 2006 to 2010. The field work was conducted between 2007 and 2009 with the approval from the University of Sydney's Human Research Ethics Committee. The preparation of this journal article is funded by a British Academy visiting fellowship at Goldsmiths, University of London from 2011 to 2012.

2 There are two courses on LGBT Studies offered by Fudan University, Shanghai: 'Homosexual Health Social Science’ (tongxinglian jiankang shehui kexue) coordinated by Professor Gao Yanning from the School of Health Sciences since 2003 and 'Gay Studies' (tongxinglian yanjiu) coordinated by Associate Professor Sun Zhongxin from Department of Sociology since 2005.

3 In China, gay weddings have not been recognised by law, although there have been repeated appeals to the state legislative body to legalise same-sex marriage rights. One of the most outspoken advocates of same-sex marriage in China is Professor Li Yinhe, China's leading sexologist from the Chinese Academy of Social Sciences. Since 2003, Li has appealed to the National people's Congress and National People's Political Consultative Conference to recognise same-sex marriage rights. Her appeals have generated heated debate in Chinese media..

4 This is an online citation. Therefore it does not have a page number. See bibliography for the web link.

5 One of the most popular questions that people ask in China when they meet for the first time is, 'where do you come from?' Where one comes from is closely associated with urban/rural divide, class and certain stereotypes about the locality. For discussions about local and translocal cultures in China, see (Goodman, 1986, 1997; Oakes \& Schein, 2006)

6 All the translation from Chinese materials into English in this article has been produced by the author unless otherwise stated.

7 Apart from reasons such as termination of land leases and demolition of old neighbourhoods, Lee San explained that one reason many gay bars in Shanghai stay closed for long periods of time is the bar owners' pragmatism. 'They do not have a sense to serve the community,' he said, 'that is why as soon as the bars do not make profits, they shut them down.' Yutian, another interviewee from Shanghai, also points out the fast changes in Shanghai's gay scene: 'New bars open and close every year. A once-most-popular bar loses its popularity in a mere few months. People crowd to others bars and forget the old ones, which close very quickly.' The Shanghai 'pragmatism' and its obsession with the 'new' will be discussed later in this article.

8 Although this article primarily deals with gay identity in contemporary China, one should not assume that China's historical past is not relevant. Indeed, today's queer sexuality is still subject to the influence of the past, and traditional concepts of gender, sexuality and identity still leave traces on contemporary queer subject formation. The rupture between the 'premodern' and 'modern' episteme of sexuality is also evident. Due to the limit of space, this article has not delved into the discussion of traditional concepts of homoeroticism. For a detailed description of homoeroticism in premodern China, see Hinsch 1990; Wu 2004 and Zhang 2001.

9 For a more detailed account of a historical review of the gay spaces in Shanghai, see the Shanghai LGBT Pride week panel discussion:

http://www.iboysky.com/inews/guonei/200906/26219.shtml.

10 Some international foundations that fund HIV/AIDS prevention in China include the Ford Foundation, Chi-Heng Foundation and the Clinton Foundation. The Chinese government, represented by the Centre for Disease Control under the administration of the Ministry of Public Health (weishengbu), has also funded a number of programs on HIV/AIDS prevention. Most of the HIV/AIDS campaigns involve mobilization of the grassroots LGBT community, which entails the funding of NGOs in different parts of China. As most of these NGOs are funded 
by 'projects' (xiangmu), a great many disappear when the projects are over. Some interviewees have remarked that these NGOs are short-lived and their work lacks sustainable goals and presence. Also, the clashes of interest between different NGOs and foundations have caused concern. At the LGBT NGO conference on HIV/AIDS held in Beijing in December, 2008, Zhang Beichuan addressed the problems of 'lack of sustainability' (quefa chixuxing) and 'internal struggle' (neihong) specifically.

11 The full name of the conference is Working Conference on HIV/AIDS Prevention and Treatment among MSM Groups, the Ten-Year Anniversary Celebration of Friends Exchange Project, and Berry \& Martin Prize Awarding Ceremony. The conference was organised jointly by the China Preventive Medicine Association and the Friends Exchange Project led by Zhang Beichuan from the Medical School of Qingdao University. I thank Professor Zhang for his kind invitation.

12 The earliest gay culture festival I have been able to locate in China was scheduled to be held in 788 art district in northeast Beijing in December 2005. It was called to a halt by police (Macartney 2005; Cristini 2006).

13 'We should not let anything happen that might embarrass the government,' Hannah Miller, organiser of the Shanghai LGBT Pride, said to the New York Times correspondent after returning from the impromptu sidewalk meeting. She explained the reason for the impromptu meeting with the Chinese police as 'that was a close call'. (Jacobs 2009) It was apparent that the event organiser negotiated with the Chinese police and both parties made some compromise. The result of the negotiation was that the Pride Week could continue but some events that might involve too many people had to be cancelled and the publicity of events had to be limited to the English-language media.

14 For a discussion of the politics of reticence in Chinese queer politics, see Liu Jen-peng and Ding Naifei 'Reticent Poetics, Queer Politics'(2005a).

15 For an explanation of the magazine title Shi $(\mathrm{Ya})$, see

http://www.tongyulala.org/communityview.php?id=122 (accessed Nov. 10, 2009). The blog of the Dian (Gayspot) magazine http://blog.sina.com.cn/gayspot (accessed Nov. 10, 2009); LES+ magazine: http://blog.sina.com.cn/lesplus (accessed Nov. 10, 2009).

\section{References}

Altman, Dennis (1996): “On Global Queering”, Australian Humanities Review, 1-9.

---- (1997): “Global Gaze/Global Gays”, GLQ: a Journal of Lesbian and Gay Studies, 3, 417436.

----- (2001): Global Sex, Chicago: University of Chicago Press.

Anderson, Benedict (1983): Imagined Communities: Reflections on the Origin and Spread of Nationalism, London: Verso.

Appiah, Anthony (2006): Cosmopolitanism: Ethics in a World of Strangers (1st ed.), New York: W.W. Norton.

Beck, Ulrich (2000): "The Cosmopolitan Perspective: Sociology of the Second Age of Modernity”, British Journal of Sociology, 51, 79-105.

----- (2002): “The Cosmopolitan Society and Its Enemies”, Theory, Culture and Society, 19, 1744.

- (2004): "Cosmopolitan Realisms: On the Distinction between Cosmopolitanism in Philosophy and Social Scences”, Global Networks, 4, 131-156.

----- (2006): The Cosmopolitan Vision, Cambridge, UK; Malden, MA: Polity Press.

(2007): “A New Cosmopolitanism Is in the Air”, Literaturen, republished by signandsite.com, http://www.signandsight.com/features/1603.html (accessed 10/11/2009). 
Bhabha, Homi K. (1994): The Location of Culture, London ; New York: Routledge.

Binnie, Jon (2006): Cosmopolitan Urbanism, London: Routledge.

Binnie, Jon \& Beverly Skeggs (2006): "Cosmopolitan Knowledge and the Production and Consumption of Sexualized Space: Manchester's Gay Village”, Jon Binnie, Julian Holloway, Steve Millington \& Craig Young (eds): Cosmopolitan Urbanism, London and New York: Routledge.

Bourdieu, Pierre (1984): Distinction: A Social Critique of the Judgement of Taste, Cambridge, Mass.: Harvard University Press.

Brennan, Timothy (1997): At Home in the World: Cosmopolitanism Now, Cambridge, Mass.; London: Harvard University Press.

China Daily (2009): "Pride of tolerance", 10 June: http://www.chinadaily.com.cn/cndy/200906/10/content_8266057.htm (accessed 10/11/2009).

Chou, Wah-Shan (2000): Tongzhi: Politics of Same-Sex Eroticism in Chinese Societies, New York: Haworth Press.

Collins, Andrew (2009): “Gay Bars in Shanghai”: http://gaytravel.about.com/od/nightlife/qt/Shanghai_bars.htm (accessed 10/11/2009).

Cristini, Remy (2006): “Whose Comrades? Gay Festivals in China”, IIAS Newsletter, 41.

Deleuze, Giles \& Guattari, Felix (1983): Anti-Oedipus: Capitalism and Schizophrenia, London: Continuum.

D'Emilio, John (1997): “Capitalism and Gay Identity”, Roger N. Lancaster (eds): The Gender/Sexuality Reader: Culture, History, Political Economy, New York and London: Routledge.

Donald, Stephanie et al. (2009): Branding Cities: Cosmopolitanism, Parochialism, and Social Change, New York; London: Routledge.

Farrer, James (2002): Opening Up: Youth Sex Culture and Market Reform in Shanghai, Chicago: University of Chicago Press.

Foucault, Michel (1977): Discipline and Punish: The Birth of the Prison, New York: Pantheon Books.

----- (1978): The History of Sexuality, New York: Pantheon Books.

----- (1986): “Of Other Spaces”, Diacritics, 16, 22-27.

Gao, Yanning (2006): Tongxinglian Jiankang Ganyu (Homosexual Health Intervention), Shanghai: Fudan Daxue Chubanshe.

Harvey, David (2009): Cosmopolitanism and the Geographies of Freedom, New York: Columbia University Press.

He, Xiappei (2006): 'I Am AIDS': Living with the Epidemic in China, [Unpublished Ph.D. Thesis], London: University of Westminster.

Hershatter, Gail (1997): Dangerous Pleasures: Prostitution and Modernity in Twentieth-Century Shanghai, Berkeley: University of California Press.

Hinsch, Bret (1990): Passions of the Cut Sleeve: the Male Homosexual Tradition in China, Berkeley: University of California Press.

Ho, Loretta Wing Wah (2005): “Opening Up: Articulating a Same-Sex Identity in Beijing”, 1st International Conference of Asia Queer Studies, Permanent Archive of Sexualities, Genders and Rights in Asia: http://bangkok2005.anu.edu.au/papers.php (accessed 10/11/2009).

Jacobs, Andrew (2009): “Gay Festival in China Pushes Official Boundaries”, The New York times, 14 July:

http://www.nytimes.com/2009/06/15/world/asia/15shanghai.html?pagewanted=1\&_r=2\&ref=gl obal-home (accessed $10 / 11 / 2009$ ).

Jiang, Jin (2009): Women Playing Men, Yue Opera and Social Change in Twentieth-Century Shanghai, Seattle and London: University of Washington Press. 
Jones, Rodney H. (2007): “Imagined Comrades and Imaginary Protections: Identity, Community and Sexual Risk among Men Who Have Sex with Men in China”, Journal of homosexuality, 53:3, 83-115.

Kang, Wenqing (2009): Obsession: Male Same-Sex Relations in China, 1900-1950, Hong Kong: Hong Kong University Press.

Kipnis, Andrew (2006): “Suzhi: A Keyword Approach”, Chian Quarterly, 186, 295-313.

Lee, Leo Ou-fan (1999): Shanghai Modern: The Flowering of a New Urban Culture in China. 1930-1945, Cambridge, Mass.: Harvard University Press.

Lefebvre, Henri (1991): The Production of Space, Oxford, OX, UK; Cambridge, Mass., USA: Blackwell.

Liang, Samuel Y. (2010): Mapping Modernity in Shanghai: Space, Gender, and Visual Culture in the Sojourners' City 1853-98, London: Routledge.

Li, Dun (2004): Aizibing Zai Zhongguo: Falv Pinggu Yu Shishi Fenxi (Hiv/Aids in China: Legal Assessment and Factual Analysis), Beijing: Shehui kexue wenxian chubanshe.

Macartney, Jane (2005): “Police Call Halt to China's First Gay Cultural Festival”, Timesonline, 17 December: http://www.timesonline.co.uk/tol/news/world/asia/article767059.ece (accessed 10/11/2009).

Martin, Fran (2008): Asiapacifiqueer: Rethinking Genders and Sexualities. Urbana: University of Illinois Press.

Martin, Fran et al. (2003): Mobile Cultures: New Media in Queer Asia, Durham; London: Duke University Press.

Marx, Karl \& Friedrich Engels (1977): The Communist Manifesto, Middlesex, England: Penguin Books.

Morgan, Diane \& Gary Banham (2007): Cosmopolitics and the Emergence of a Future, Houndmills, Basingstoke: Palgrave Macmillan.

Ong, Aihwa (1999): Flexible Citizenship: The Cultural Logics of Transnationality, Durham, NC: Duke University Press.

Robbins, Bruce et al. (1998): Cosmopolitics: Thinking and Feeling Beyond the Nation, Minneapolis: University of Minnesota Press.

Rofel, Lisa (1999): Other Modernities: Gendered Yearnings in China after Socialism, Berkeley: University of California Press.

----- (2007): Desiring China: Experiments in Neoliberalism, Sexuality, and Public Culture, Durham: Duke University Press.

Sang, Tze.-lan Deborah (2003): The Emerging Lesbian: Female Same-Sex Desire in Modern China, Chicago and London: The University of Chicago Press.

Schein, Louisa (1999): “Of Cargo and Satellites: Imagined Cosmopolitanism”, Postcolonial studies, 2(3), 345-375.

Sedgwick, Eve. K. (1990) Epistemplogy of the Closet, Berkeley: University of California Press.

Sigley, Gary (2009) "Suzhi, the Body, and the Fotunes of Tchnoscientific Reasoning in Contemporray China”, Positions: East Asia Cultures Critique, 17(3), 537-566.

Sullivan, Gerard, \& Peter A. Jackson (2001): Gay and Lesbian Asia: Culture, Identity, Community, New York: Harrington Park Press.

Tattleman, Ira (2000): "Presenting a Queer (Bath) House”, Bonne Joseph A. (eds): Queer Frontiers - Millenial Geographies, Genders and Generations, Madison: University of Wisconcin Press.

The Independent (2008): “The Five Most Improved Places for Gay Tolerance”, 17 September: http://www.independent.co.uk/life-style/love-sex/taboo-tolerance/the-five-most-improvedplaces-for-gay-tolerance-932635.html (accessed 10/11/2009).

Tomba, Luigi (2009) "Of Quality, Harmony, and Community: Civilization and the Middle Class in Urban China”, Positions: East Asia Cultures Critique, 17:3, 592-616. 
Tong, G. (2008): “'Tongzhi wangzhan': 'tongzhi shequ' de zifa jiangou”, G. Tong et al. (eds): Zhongguo tongzhi renqun shengtai baogao (Ecological report on the Chinese homosexual population), Beijing: Beijing Gender Health Education Institute.

Utopia Asia (2009): “Shanghai: general information”: http://www.utopia-asia.com/chinshan.htm (accessed 10/11/2009)

Visser, Robin (2010): Cities Surround the Countryside: Urban Aesthetics in Postsocialist China, Durham: Duke University Press.

Wang, Yiyan (2007): "Shanghai Modernity: Women and the Practice of Everyday Life", Literature \& Aesthetics, 17(1173-187).

Wasserstrom, Jeffrey N. (2009): Global Shanghai, 1850-2010: A History in Fragments, London: Routledge.

Weber, Max (1976): The Protestant Ethic and the Spirit of Capitalism (2nd ed.), London: Allen \& Unwin.

Woronov, Terry (2009) “Governing China's Children: Governmentality and the 'Education for Quality”, Positions: East Asia Cultures Critique, 17:3, 567-589.

Wu, Cuncun (2004): Homoerotic Sensibilities in Late Imperial China, London and New York: RoutledgeCurzon.

Yang, Mayfair Mei-hui (1997): "Mass Media and Transnational Subjectivity in Shanghai: Notes on (Re)Cosmopolitanism in a Chinese Metropolis”, Aihwa Ong \& Donald Macon Nonini (eds): Ungrounded Empires: The Cultural Politics of Modern Chinese Transnationalism, New York and London: Routledge, 287-319.

Yatsko, Pamela (2003): New Shanghai: The Rocky Birth of China's Legendary City, Hoboken N.J. : John Willey \& Sons (Asia) Pte Ltd.

Zhang, Haoyin (2003): Shanghai Wanshi (Past Things in Shanghai), Nanning: Guangxi renmin chubanshe.

Zhang, Zaizhou (2001): Aimei de licheng: Zhongguo gudai tongxinglian shi (An Intimate Journey: a History of Homoeroticism in Premodern China), Zhengzhou: Zhongzhou gu ji chu ban she. 